The International Conference Going Global through Social Sciences and Humanities

GGSSH 2019: Going Global through Social Sciences and Humanities: A Systems and ICT Perspective pp 136-144| Cite as

\title{
Using LMS Moodle for Mastering English Skills as an Interactive Competition Tool
}

- Authors

- Authors and affiliations

- Ksenia A. Girfanova

- Inna A. Cheremisina Harrer

- Liudmila V. Anufryenka

- Alena V. Kavaliova

\section{Abstract}

The paper outlines the use of Learning Management System Moodle as a tool for running an international competition in English. Since 2012 partner universities from Russia, Belarus and Ukraine have initiated an international student competition in English based on the facilities and resources of the Moodle platform. The participating students from partner universities were exposed to interactive activities and networking resources with the aim to demonstrate and master their English and communication skills. The use of virtual learning environment was intended to assist students in developing their digital competence as well. The competition included several rounds based on different Moodle features and services and enabled the participants to demonstrate their skills in listening comprehension, reading comprehension, use of English, creative writing, and public speech. The participation of students from different universities and managing the English competition by an international team of teachers are described as challenging experiences that resulted for both sides in promoting their personal and professional development.

\section{Keywords}

Learning management system moodle English and communication skills Interactive competition 


\section{References}

1. 1.

Cisco

Homepage. http:// www.cisco.com/c/ dam/ en us/about/ citizens hip/socio-economic/docs/ATC21S_Exec_Summary.pdf. Last accessed 02 J uly 2018

British Council

Homepage. https:// www.britishcouncil.vn/ en/programmes/ edu cation/connecting-classrooms/ core-skills-for-learning-workand-society. Last accessed 22 J uly 2018

Fullan, M., Langworthy, M.: A Rich Seam. How New Pedagogies Find Deep Learning. Pearson, Toronto (2014) Google Scholar

4. 4.

New pedagogies for deep learning Homepage. http:// npdl.global. Last accessed 22 J uly 2018

5. 5.

Younghee, N.: A study on the effect of digital literacy on information use behavior. J . Libr. Inf. Sci. 49(1), 26- 56 (2017) Google Scholar

6. 6.

Hobbs, R.: Digital and Media Literacy: A Plan of Action. The Aspen Institute, Washington (2010)Google Scholar

Kwon, S., Hyun, S.: A study of the factors influencing the digital literacy capabilities of middle-aged people in online learning. Korean J . Learn. Sci. 8(1), 120- 140 (2014)Google Scholar 
8. 8.

Moodle Homepage. http:// moodle.net/ sites. Last accessed 16 July 2018

9. 9.

Tomsk Polytechnic University Electronic Learning Homepage. http:// portal.tpu.ru/ eL. Last accessed 22 J uly 2018

10. 10.

Rymanova, I., Baryshnikov, N., Grishaeva, A.: E-course based on the LMS Moodle for English language teaching. Development and implementation of results. Soc. Behav. Sci. 206, 236- 240 (2015)CrossRefGoogle Scholar

11. 11.

Kazatchyonok, V.V., Mandrik, P.A.: Primenenie IKT v vyschem obrazovanii Respubliki Belarus [Use of computer technologies in higher education in the Republic of Belarus]. In: Viktorov, A., Ovodenko, A. (eds.) Primenenie IKT v vyschem obrazovanii stran SNG i Baltii: tekushchee sostojanie, problemy i perspektivy rasvitija [Use of information computer technologies in higher education in the CIS and Baltic States: state-of-the-art, challenges and prospects for development], pp. 41- 54. GUAL publishing centre, St. Peterburg (2009) (in Russian) $\underline{\text { Google }}$ Scholar

12. 12 .

Robert, I.V.: Sovremennye informatsionnye technologii v obrazovanii [Modern information technologies in education]. Shkola-Press Publishers, Moscow (2004). (in Russian)Google Scholar

13. 13.

Khamitseva, S.F.: Komp'uternye tekhologii v obuchenii inostrannym jazykam [Computer technologies in teaching 
foreign languages]. Molodoj uchenuj 8, 1057- 1059 (2015). (in Russian)Google Scholar

14. 14.

Zubov, A.V.: Metodika primenenija informatsionnyh technologij v obuchenii inostrannomy jazyku [Methods of using information technologies in teaching a foreign language]. Akademia Publishers, Moscow (2009). (in Russian) Google Scholar

15. 15.

Dichkovskaya, E.A.: Ispolsovanie komp'uternyh tekhnologij v obuchenii inostrannym jazykam. [Use of computer technologies in teaching foreign languages]. Teorija i praktika professionalnogo obuchenija inostrannym jazykam. In: Shimanskaya, O.Y. (ed.) Teorija i praktika professionalnogo obuchenija inostrannym jazykam [The theory and practice of professional foreign languages teaching], Conference 2013, pp. 28- 31. MITSO, Minsk (2013) (in Russian) Google Scholar

16. 16.

Dofs, K., Hobbs, M.: Autonomous language learning in selfaccess spaces: moodle in action. Stud. Self Access Learn. J . 7(1), 72- 83 (2016) Google Scholar

17. 17.

International Internet English Competition Homepage. http:// web.tpu.ru/ webcenter/portal/iyaei/mio? adf. ctrl-state=f0rsl33vi_21. Last accessed 22 J uly 2018

18. 18.

Avanesov, V.S.: Kompozicija testovyh zadanij. [Composition of tests]. Centr testirovanija Publishers, Moscow (2002) (in Russian)Google Scholar 


\section{Cite this paper as:}

Girfanova K.A., Cheremisina Harrer I.A., Anufryenka L.V., Kavaliova A.V. (2019) Using LMS Moodle for Mastering English Skills as an Interactive Competition Tool. In: Anikina Z. (eds) Going Global through Social Sciences and Humanities: A Systems and ICT Perspective. GGSSH 2019. Advances in Intelligent Systems and Computing, vol 907. Springer, Cham. https://doi.org/10.1007/978-3-030-11473-2_16

- First Online09 February 2019

- DOlhttps://doi.org/10.1007/978-3-030-11473-2_16

- Publisher NameSpringer, Cham

- Print ISBN978-3-030-11472-5

- Online ISBN978-3-030-11473-2

- eBook Packages Intelligent Technologies and RoboticsIntelligent Technologies and Robotics (R0)

https://link.springer.com/chapter/10.1007\%2F978-3-030-11473-2 16 